第 6 表 排脱操業データの 1 例

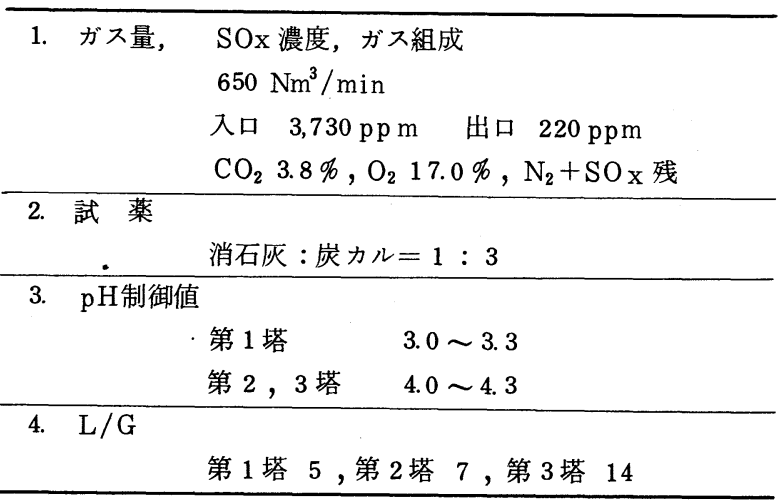

る脱硫設備を設置し稼動させた（昭 51 )。吸収塔（モレタナ式） は 2 塔直列で, 消石灰, 炭カルをそれぞれのビンより吸収スラリ 一の $\mathrm{pH}$ Hながら補給した。反応生成物は亜石膏を多く含み, 加王式沪過器で沪過後, 一部は $\mathrm{Ca}$ 源として焼結機に繰返し, 残 りは積置いた。 2 年間の操業経験のあと, 原料ガスの酸素濃度が 比較的高いことから, 吸収液の $\mathrm{L} / \mathrm{G}, \mathrm{pH}$ を適当に設定すれば, 特別に酸化装置をもたなくとも $99.5 \%$ 以上の石高が生成すると 判り，そのように工程を変えた。すなわち，吸収塔をシリーズに 1 塔増して, $\mathrm{pH}$ を 2 段制御とし, 沪過器は遠心分離機にした。 その結果昭和 54 年 8 月より, 生成石膏は全量, 直島吉野石膏(株) に送られている。主要データを第 6 表に示す。

\section{$3 \cdot 5$ 精鉱の組成变化とその対応 (昭 54〜)}

近時原鉱の $\mathrm{MgO}, \mathrm{b}$ i tumen 含有量が増してきた。前者につ いては溶剤の使用量を增して稀釈することで対応しているが，溶 凨節減のため鍰の組成变更を研究中である。後者については, 焼 結ガスバッグの目詰りによる寿命短縮，煙灰の着火性上昇，さら に硫酸工場での脱色試薬の消費増という問題をかかえており, 諸 対策を検討中である。精鉱の最近の分析例を第 3 表に示す。なお， $\mathrm{n}$ 一ヘキサン抽出分は bitumen 含有量の目安として分析してい る。

\section{4. むす び}

当工場はパインポイント鉱の専用製鍊所として誕生し, 爾来, 操業の安定, 省エネ, 省力化, 物品の節減, 鉛実収率と製品品質 の向上，さらには環境対策に取組みつつ，14 年が過ぎた。次の 10 年もパインポイント鈗の単独使用といら宿命のもとで生きてい かねばならない。上昇の著しい諸コストの吸収策として, 生産量 を律している焼結機の能力増による増産も一策であろう（鉱石供 給の問題もあるが)。急上昇を続けるエネルギーコストに対応し て, 一層の省エネ, 燃料の代替化も必要であろう。もちろん, 省 力化, 物品節減も一段と進めなければならない。

今後も総力をあげて操業の進歩に努め, 10 年後の本誌特集号で の内容が，充実し変化に富んだものでありたい，と切望するもの である。

\title{
Lead Smelting at Naoshima, Mitsubishi-Cominco
}

\section{by Shizuo KAWAKITA}

Mitsubishi Cominco Smelting Co. is a joint venture of Mitsubishi Metal Corp. of Japan and Cominco Ltd. of Canada. The smelter, which is located alongside Mitsubishi's Naoshima Copper Smelter, started its production in October, 1966 and has a capacity of 36,000 tons per year of refined lead with five $-9^{+}$purity.

The concentrate feed for the smelter from Pine Point Mine of Cominco is of high grade with low levels of impurities, being particularly low in silver, bismuth, antimony and arsenic, which facilitated a compact plant layout and operation. Concentrate, fluxes, recycle granulated slag and return sinter are drawn from bins by automatic control over weigh belt feeders. Sintering is carried out on a $20 \mathrm{~m}^{2}$ Lurgi updraft sintering machine, furnacing in a $1.4 \mathrm{~m} \mathrm{x} 3.0 \mathrm{~m}$ water-jacketed blast furnace equipped with an Asarco continuous tapper, refining in 150 ton kettles and casting on a $25 \mathrm{t} / \mathrm{h}$ automatic casting machine. The $\mathrm{SO}_{2}$ gas from sintering is cleaned in a high temperature baghouse utilizing glass bags and then delivered to the adjacent copper smelter acid plants. The furnace gas after being cleaned in a low temperature baghouse is neutralized with a mixture of slaked lime and calcium carbonate, with gypsum as the by-product. Refining is simply done by decopperizing with Al-Zn alloy and succeeding clean-up by caustic soda for the residual aluminum and zinc elimination.

\section{〔2-12]竹原製棟所における鉊製錬について}

\section{平 川 整四郎 ${ }^{1}$}

\section{1. 緒}

\section{言}

当所の鉛製鍊は，涬類を原料とする溶鍊部門と，それより産出 する粗鉛のほか, 他所より送られてくる粗鉛を精製する電解部門 より成り立つている。

電解部門は，昭和 44 年に八戸製鍊所の操業開始にあわせて，電 解槽大型化・省力化を織り込んで, 従来の $900 \mathrm{t} /$ 月設備に替えて $3000 \mathrm{t} /$ 月設備として新設されたものである。

溶鍊部門のうち溶鉱炬については, 昭和 53 年 5 月に若干の大型

1. 正会員 三井金属鉱業株式会社竹原製煉所長
化ともに，旧態化していた鉱㾏処理・鍰処理・送風・投入等の諸 設備の, 更新・省力化・作業環境の改善等を図つた。

短回転炉については, 昭和 54 年 1月に操業を開始した脱銅ドロ スのアンモニア浸出一溶媒抽出工程から産出される炭酸鉛を主原 料とし，その他涬類等の処理もあわせて行なつている。

\section{2. 最近 10 年間の推移}

\section{溶鉱炬部門 \\ 昭和 47 年10月 酸素富化操業開始}

昭和 52 年 3 月 造粒鉱の鍰焼結中止 
昭和53年 5 月 炉大型化・ブレヒータ設置・鉱煙処理・投入 設備・その他の增強

昭和 54 年 10 月 炣頂投入部改造 短回転炉部門

昭和 44 年 6 月 No 1 号炬操業開始

昭和 45 年12月 No 2 号炬操業開始， 2 炬体制となる

昭和 47 年 10 月 集塵設備増強

昭和 49 年 10 月 炬排ガス脱硫設備新設

昭和 50 年 10 月 神岡銅鈹処理開始

昭和 51 年 12 月 硫酸鉛・他原料処理開始

昭和 54 年 1 月 脱銅ドロス直接処理中止，銅浸出残渣処理に 切換元

電解部門

昭和 44 年 4 月 大型新電解槽に通電開始 ( 92 槽)

昭和 48 年 4 月 アノード鋳造省力化 ( 1 名減 )

昭和 48 年12月 鉛スライム乾燥強化

昭和 49 年 7 月 省力化実施 ( 3 名減)

昭和 49 年 11 月 製品・母板工程集塵強化

昭和 49 年12月 脱錫鍋大型化 $(200 t \rightarrow 250 t)$

昭和 50 年 11 月 省力化実施 ( 1 名減)

昭和 52 年 6 月 電解槽 4 槽増設 ( 96 槽となる)

昭和 52 年 10 月 省力化実施 ( 3 名減 )
昭和 53 年 12 月 電解液中からの除鉛設備完成

昭和 54 年 5 月 ビーム洗浄装置新設

3. 現在の操業フローシート (第 1 図参照)

\section{4. 主要設備及び操業方法 ( 現状 )}

\section{$4 \cdot 1$ 溶錬部門}

従来からの小型溶鉱炬に加え, 昭和 44 年からは短回転炬の稼動 により，異つた 2 形態の炬を持つこととなつた。昭和 51 年までは 短回転炉の原料は, 含銅鉛原料のみであつたが, 昭和 51 年末より 硫酸鉛・煙灰等銅を含まない原料の処理を開始し, 現在まで逐次 増加の傾向にある。さらに昭和 54 年初頭の溶媒抽出工場の稼動後 は，含銅ドロスをアンモニヤ及び炭酸アンモンで浸出した残渣（ 炭酸鉛）を主体に，硫酸鉛・その他の原料を処理している。

このため, 基本的な反応機構については両炉による違いはなく なり, 原料の仕分けは, 効率の良い回収方法を選ぶことを主体と して行なつている。

（1）溶釷炉 昭和 53 年に大型化された現在の炬は, 羽口準 断面積 $3.3 \mathrm{~m}^{2}$, 長さ $2.4 \mathrm{~m}$, 幅 $1.6 \mathrm{~m}$ の長円型で, 羽口数は 20 本であ る。装入はトップチャージで, 廃ガスはサイドティクで吸引して いる。炉高は $6.3 \mathrm{~m}$ あり, 装入準から下部 $2 \mathrm{~m}$ は水套とし, 炬体に 付着したべコ等の除去作業を容易にしている。

送風空気は, 重油焚きの予熱器により最高 $430^{\circ} \mathrm{C}$ まで加温するとともに, 酸素富化もで きるようにしてあり，炬況に応じて操業でき る。

排ガスの処理は，ダストチャンバーバルン 煙道 $\rightarrow$ アピンクーラ $\rightarrow$ ストスチャンバ $\rightarrow$ ス グフィルタ 排風機の系統で行なつている。 ヘアピンクーラは冷却面積 $650 \mathrm{~m}^{2}$ を持ち, 水 冷部・バイパス煙道等を有し, 天候の変化に 応じ調整できるようにしてある。また，バグ フィルタは $750 \mathrm{~m}^{2}$ の沪過面積を持ち,ナイロ ン洰布を使用している。排風機は $600 \mathrm{Nm}^{3}$ / $\min \times 600 \mathrm{mmAq} \times 135 \mathrm{~kW}$ である。

サイホンにより炉から取出された粗鉛は, 直ちに除渣鍋 (容量 $4 \mathrm{t}$ ) に受け, 浮上した ドロスを機械的に除去後, 鋳型に流して $2 \mathrm{t}$ の鋳塊に鋳込み，電解工場に運搬している。

鈹・鍰は前床に流入し，比重差により分離 され，鍰は溢流させ鍰鋳造機により塊状に鋳 造され，鈹は前床の底部に設けた抜出し口よ り間歇的に砂床に拔出される。前床は熱放散 により低下する温度を補うため, 300 KVA エ ル゚ー式電気炉となつている。

操業に当つては, 原料繰り及び電解部門の 陽極中の成分分析結果を見て原料の調合比率 を決定するとともに, 酸素富化率等の調節を 行なつている。また原料の内, 古基板・塊原 料は直投とし, 粉原料のみ溶鉣炉煙灰と混合 造粒し, 乾燥後炬に供用している。

（2）短回転䗆原料は還元剤及び溶剤 とともに調合した上, 炬に供用し, 重油焚き バーナで加熱溶融後抜出すと言うバッチ操業 を行なつている。鍰・粗鉛とも一旦レードル に移し, 鍰を流出除去後, 電解部門の粗鉛溶 
第 1 表 昭和 54 年度の平均分析品位

\begin{tabular}{|c|c|c|c|c|c|c|c|}
\hline 項 目 & $\begin{array}{c}\mathrm{Au} \\
(\mathrm{g} / \mathrm{t})\end{array}$ & $\begin{array}{c}\mathrm{Ag} \\
(\mathrm{g} / \mathrm{t})\end{array}$ & $\begin{array}{c}\mathrm{Cu} \\
(\%)\end{array}$ & $\begin{array}{l}\mathrm{Pb} \\
(\%)\end{array}$ & $\begin{array}{l}\mathrm{Bi} \\
(\%)\end{array}$ & $\begin{array}{l}\mathrm{Sb} \\
(\%)\end{array}$ & $\begin{array}{c}\mathrm{Sn} \\
(\%)\end{array}$ \\
\hline 溶鈗炬原料 & 3.4 & 362 & 0.98 & 62.19 & 0.38 & 1.78 & 0.76 \\
\hline 粗鉛 & 5. 4 & 553 & 0.35 & 93. 54 & 0.56 & 2. 54 & 0.77 \\
\hline 煙灰 & - & 9 & 0.05 & 50.71 & 0.37 & 0.42 & 1.43 \\
\hline マット & 0.1 & 59 & 3. 24 & 4. 37 & 0.01 & 0.59 & 0.59 \\
\hline 鍰 & 0.1 & 12 & 0.15 & 1. 10 & 0.01 & 0.24 & 0.44 \\
\hline 回転炉原料 & 16. 7 & 1,115 & 3. 79 & 61. 22 & 0.28 & 1. 46 & 1. 41 \\
\hline " 粗鉛 & 28. 9 & 1,793 & 1. 85 & 92. 59 & 0.45 & 1. 57 & 2. 32 \\
\hline 溶解ドロス & 10.5 & 1,028 & 6. 43 & 69. 97 & 0.25 & 3. 14 & 2. 08 \\
\hline 脱 錫 涬 & 1. 0 & 118 & - & 14. 57 & 0.05 & 0.93 & 16. 05 \\
\hline スラ & 225 & 57,229 & 2. 35 & 13. 03 & 14. 43 & 46. 48 & - \\
\hline
\end{tabular}

解鍋に移し替えている。

炬は 2 炬あり, $2.5 \mathrm{~m} \phi \times 2.8 \mathrm{~mL}, 3.1 \mathrm{~m} \phi \times 3.1 \mathrm{~mL}$ の内法で, バ 一ナの直上に煙道があり，煉瓦はマグネシア煉瓦を使用している。 廃ガスは水冷煙道及び空冷煙道を通り, パイブクーラで所要温度 まで泠却した後, バッグフィルタで粉塵を除去している。粉塵を 除去されたガスはさらに脱硫スクラバに導入され, 洗浄後大気中 に放出している。

\section{$4 \cdot 2$ 電解部門}

電解では分離しがたい成分を乾式法で取除く脱錫工程と, 電解 工程と，さらに精製を行なう精鉛工程の 3 工程から成立つており， 中間物・㳯類を原料とする溶鉱炬及び, 短回転炬からの多くの有 価金属を含有した粗鉛や，八戸製鍊所，三池製煉所，その他所外 から集つてきた粗鉛を使用し, 安定して高純度の電気鉛を生産す る上で, 各工程とも重要な働らきを持つている。以下各工程ごと に説明を加える。

（1）脱錫工程 容量 $200 \mathrm{t}(4.56 \mathrm{~m} \phi \times 2.16 \mathrm{mD})$ の鍋 2 基と $250 \mathrm{t}(4.56 \mathrm{~m} \phi \times 2.46 \mathrm{mD})$ の鍋 3 基を持ち, 常時 4 基を稼動させ て, 溶解，脱銅，脱錫，陽極鋳造の各操作を行なつている。

溶解・脱銅では, 粗鉛を溶解後, 粗鉛の温度を $380^{\circ} \mathrm{C}$ 前後まで 下げた後，攪拌機により機械的に攪汼を行ない，銅分を浮上させ ドロスとして分離除去を行なう。この際，粉化を容易にするため, 鋸屑等を使用している。ドロスはクレーンによりバケットで掬い 取り, 粗鉛はポンプで次の脱錫鍋へ流送する。粗鉛中の銅分は, $0.1 \%$ 以下であり,ドロス中の銅品位は 5〜20\%である。

脱錫鍋では, $400{ }^{\circ} \mathrm{C}$ 以上に粗鉛の温度を上げた後, 苛性ソーダ

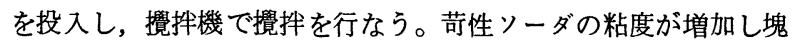
状になつたら除去する。粗鉛中の成分としては, 垔鉛・砒素・錫 ・アンチモンの順に酸化して苛性ソーダと反応するが，われわれ が行なつている範囲では, アンチモンが苛性ソーダと反応し除去 されてしまうことはほとんどない。粗鉛中の錫含有率は $0.02 \%$ 以 下となり, 脱錫涬中の錫は 7 20\%となつている。脱錫の完了し た粗鉛は次に陽極鋳造用の鍋にポンプで送られる。

陽極鋳造鍋では，脱錫の完了した粗鉛と一部不純物の少ない粗 鉛, 及び電解工程からの陽極屑とを一緒に溶解した後, ドロス除 去を行ない，陽極鋳造機により陽極とする。鋳造は 1 方で行ない 電解工程の必要枚数を鋳造する。

陽極は $360 \sim 430 \mathrm{~kg}$ の単重で, 電解日数及び電流密度により重 量を調節している。

（2）笔解工程陰極の在槽日数は $3 \sim 5$ 日, 陽極の在槽日 数は 7〜10日で, 中間でスクラップ洗浄機によりスライムの除去 を行なつて入替を行なつている。電流密度は夜間電力の利用率を 高めるため, $55 \sim 124 \mathrm{~A} / \mathrm{m}^{2}$ と変動させている。

電解夜中の鉛濃度を低下させるため, 硫酸により除去する設備 を設け, 液抵抗の上昇を防いでいる。

（3）精鉛工程電槽より引揚げられた析離鉛は, ビームを
拔いた後積重ねられてコンベヤにより搬送され，精鉛鍋に投入さ れる。精鉛鍋では溶解し, ドロス除去後苛性ソーダにより最終的 な精製を行ない，高純度の電気鉛とする。鍋は 4 基あり，容量 80 $\mathrm{t}$ の 2 基は隣接する鉛化成品工場に溶体のまま送湯するためであ $\eta, 50 \mathrm{t}$ の 1 基は D M機用, $100 \mathrm{t}$ の 1 基は外販される $50 \mathrm{~kg}$ 塊 用であり鋳造機が付属している。

析離鉛から引抜かれたビームは, 搬送中に洗浄・研磨され, 陰 極板製作機に供給される。

5. 操業成績, 主要原単位 (第 2 因, 第 3 図参照)

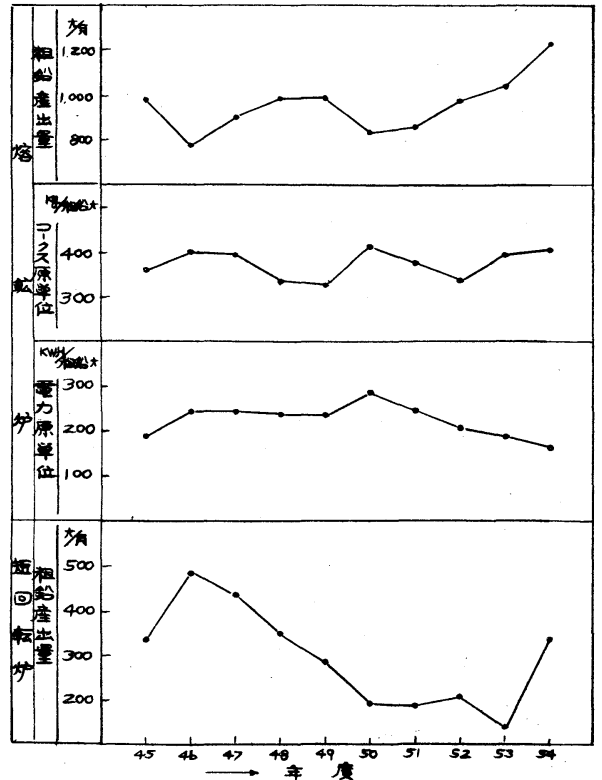

(1)

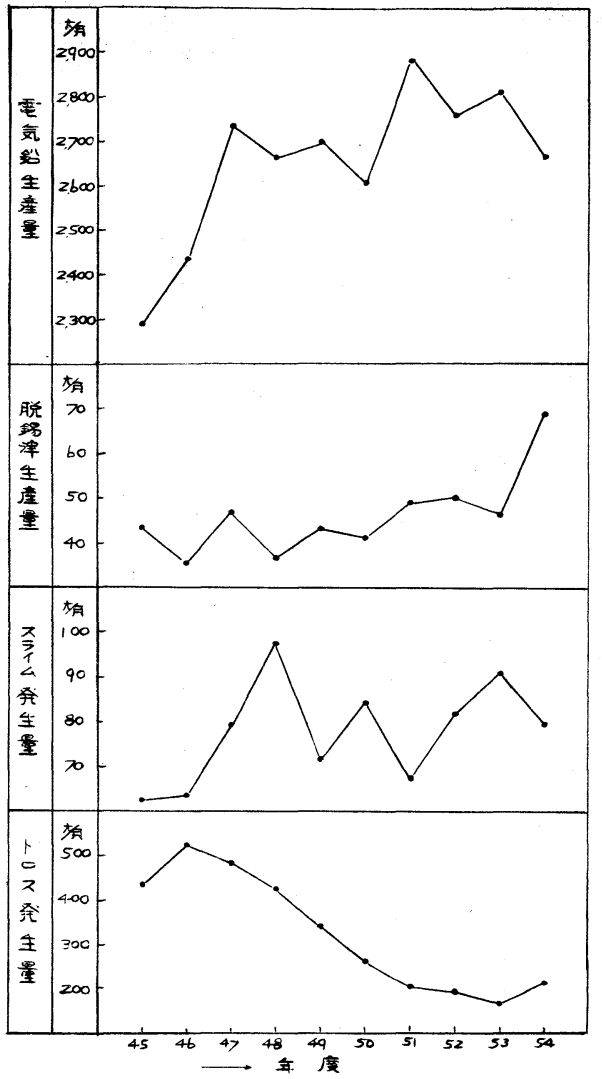

(2) 


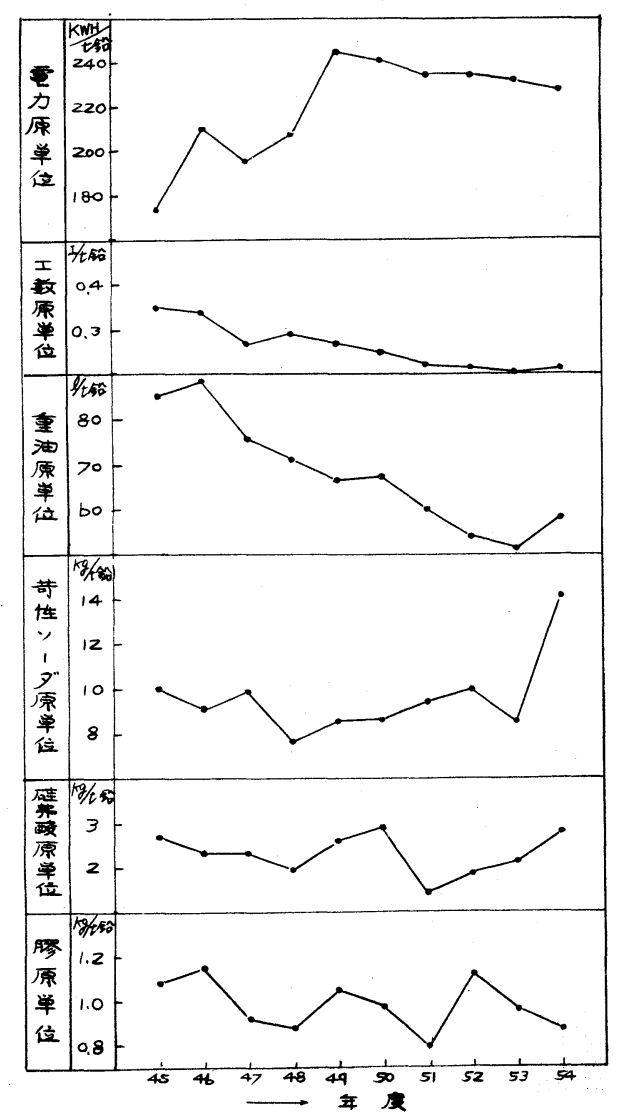

第3図

電解部門の

操業成績・

主要原単位

\section{第 4 図}

過去 10 年間の 生産量の推移

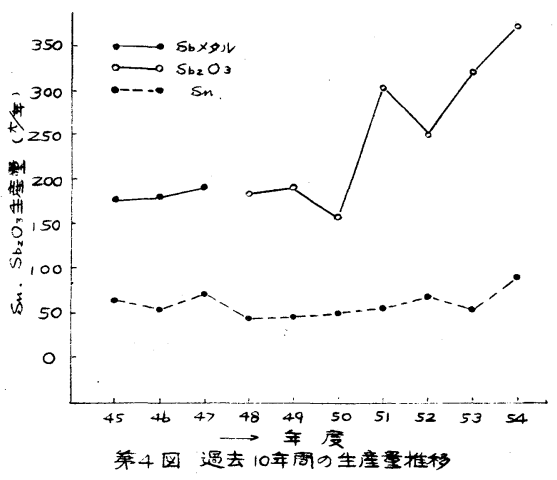

7. 環 境 対 策

\section{$7 \cdot 1$ 析離鉛溶解時の悪奥対策}

析離鉛表面に付着した電解液のため，溶解時に発生する悪臭を 除去する目的で，スクラバを設け，鍋上部から吸引したガスの洗 浄を行なつている。結果は概ね良好で問題は解消された。

なお，洗浄液は電解液にもどしている。

\section{$7 \cdot 2$ 溶釷炉放出喓道への漏煙検出器の取付}

炬ガス及び各部所からの吸引ガスのバッグフィルタ，スクラバ 等, 清浄機後のガスの流れる煙道に漏煙検出器を取付け, 洰布の 破れ等が直ちに警報として察知できるようにした。

\section{8. 副産物の回収}

\section{$8 \cdot 1$ 脱錫漳からの錫の回収}

ハリス法により，粗鉛中の錫を濃縮した脱錫㳯を水で抽出し， 若干の液清浄後, 電解液として電解採取により電気錫を生産する。 また，製品に鋳造する際発生するドロスを還元し，粗錫フノード として水溶液電解により電気錫とする。両者合わせて約 $10 \mathrm{t} /$ 月の 電気錫を生産している。純度は $99.5 \%$ 以上である。

抽出残渣にはテルルが濃縮していることより，銅部門のテルル 回収工場に送り，テルルを回収している。

\section{$8 \cdot 2$ 電解スライムからのアンチモンの回収}

スライム中の有価金属を個別に分離回収するため, 次の操作を 行なつている。まず，スライムを750KVAエルー式電気炉により還 元メタルとし，これを揮発鍋にて空気酸化し，銨を煙灰として除去 し,他の成分を残留鉛としてメタル内に残す。煙灰としてバグフィ ルタで捕集された酸化アンチモンは, 三酸化アンチモンとして外販 されている。残留鉛は，酸化炉によりビスマス・鉛を密陀として 除去後粗銀とし, 銅電解部門の粗銀と共に電解精製される。

$8 \cdot 3$ 錫及びアンチモンの回収量 (生産量)

第 4 図の通りである。

\section{9. 今後の課 題}

当所溶鉱炬の特徵である，有価物回収を主体とした姿勢をさら に強化するとともに，鉛化成品を育成してきた経験を基に，鉛加 工品等への進出を図つて行きたい。

また時代の要請である省エネルギーに継続的に取組んで行きた い。

\section{Lead Operation at Mitsui's Takehara Refinery}

by Seisiro HIRAKAWA

Takehara Lead Refinery is designed to produce high quality electrolytic lead and many other by-products both from secondary lead-bearing materials and from purchased bullion.

For treatment of various kinds of secondary lead materials, Takehara lead smelting operation consisting of a blast furnace and two short rotary furnaces is suitable and advantageous in respect to recovery of valuable metals and fixation of hazardous elements. The smelter feed is made up of lead-bearing materials, limestone, and iron scrap. Charge of iron scrap fixes sulphur in the matte without any environmental problems. 


\section{鉛・亜鉛製鍊}

The refinery plates out pure lead on lead cathode starting sheets in a hydrofluosilicic acid electrolyte, and leaves antimony, bismuth, gold, and silver to be recovered from the anode slimes. Meanwhile copper and tin are removed as dross or caustic soda scum produced at bullion melting kettles.

Refined cathodes are melted, fluxed with caustic soda, and cast for market or pumped to the lead chemical operations. In the smelting or the refining operation, antimony oxide, gold, silver, tin, tellurium, bismuth, and indium are recovered as by-products.

\section{〔2-13]契島製鍊所の鉊製鍊}

\section{1. 緒}

当所は竹原市港外約 $4 \mathrm{~km}$ の, 瀬戸内海国立公園に浮かぶ小島 の, 鉛単独製鍊所である。昭和 26 年, 自山鉱である対州, 南越鉱 を主体に鉛の生産を開始し, 以来, 経済の発展とともに, 設備拡 充を計り，近年はほとんどが輸入鉱の買鉱製鍊所として発展して きた。

現在の生産品目及び月産能力は, 第 1 表の通りである。

第 1 表

\begin{tabular}{llr|r|llll|r}
\hline 電 & 気 & 鉛 & $6,000 \mathrm{t}$ & 蒸 & 留 & 亜 & 鉛 & $430 \mathrm{t}$ \\
電 & 気 & 銀 & $11 \mathrm{t}$ & 硫 & 酸 & 亜 & 鉛 & $300 \mathrm{t}$ \\
粗 & & 金 & $100 \mathrm{~kg}$ & 濃 & 硫 & 酸 & $3,200 \mathrm{t}$ \\
電気ビスマス & $5 \mathrm{t}$ & 石 & & & 膏 & $2,500 \mathrm{t}$ \\
\hline
\end{tabular}

\section{2. 設備の変遷}

\section{$2 \cdot 1$ 溶錬部門}

昭和 44 年, 大型 DL $\left(30 \mathrm{~m}^{2}\right)$ を新設, 既設 D L $\left(10.8 \mathrm{~m}^{2}, 7.8\right.$ $\left.\mathrm{m}^{2}\right)$ と併せ一段焼結に切替え, 従来のへレショフ式焙焼炉は全廃 した。

45 年, DLでのガスの導入及び捕集方法等の工程改善により, 濃硫酸の生産を， $1,500 \mathrm{t} /$ 月から $3,000 \mathrm{t} /$ 月へと倍増することが できた。

46 年, B Fドロス処理の重油焚反射炉を $1,000 \mathrm{kVA}$ 電気炉に 切替え, 能力向上, 省力化をはかつた。

47 年, DL操業の安定化により, 小型 2 基を廃し, $30 \mathrm{~m}^{2} \mathrm{DL}$ 1 基のみとした。

49 年, DL 返鉱製造設備を設け, 調合の安定化を計るとともに, $\mathrm{B} F$ の炉床面積を拡大 $\left(8.38 \rightarrow 9.35 \mathrm{~m}^{2}\right)$, 種々の雑物処理にも対 応できるようにした。 50 年, さらにBFへのチャージング設備の 自動化による荷高の一定化と, 炉ガス温度コントロールシステム を確立することにより, 操業の安定化及び省力化を一段と推進さ せた。 51 年, 従来からの懸案であつた B F スラグから「Zn回収」 を三井金属鉱業(株)から技術導入することを決定, 52 年より $\mathrm{PW}$ 亜鉛として回収し, 回収後のスラグはセメント用として外販を開 始した。

\section{$2 \cdot 2$ 錬部門}

44 年, 所内電源の海底ケーブルを $110 \mathrm{kV}, 20,000 \mathrm{kVA}$ に更新, 同時に 39 年により着手していた大型電槽 (カソード $1,080 \mathrm{~mm} \times 840 \mathrm{~mm}$ ) 化が完成し, 上記大型 D L の導入と併せ, 電気鉛 $6,000 \mathrm{t} /$ 月体制が整つた。

一方, 30 年代後半から実施していたスライム脱水液の浄液電

1. 正会員 東邦德鉛侏式会社契島製鍊所副所長

\section{山北 輝 雄 ${ }^{1}$}

解を, 41 年に拡張した。電解液の $\mathrm{Pb}$ 濃度調整用としても, 品質 及び電力原単位等, 操業の安定化に寄与している。

49 年に始めた $4-3$ 制の導入及び休日の増加等に対応して, 51 年, 7 日間電解方式への移行, さらに 53 年には, アノードの立型 自動鋳造機の開発及びカソードから精製鋳造工程における荷役運 搬設備の合理化等を実施，相当数の省力化をはかつた。

次いで 55 年, アノードとアノードスクラップの受払関係及び, 極板の同時脱着配列システムの自動化を実施, 作業の能率化と省 力化をはかつた。人員の推移は第 2 表の通りである。

第 2 表 電解鋳造部門における人員の推移

\begin{tabular}{|c|c|c|c|c|c|}
\hline 45 年 & 68 名 & 50 年 & 49名 & 55 年 & 30 名 \\
\hline
\end{tabular}
充した。さらに 46 年, 脱鉸までのスライム処理工場を全面的に 更新し，電気銀 $11 \mathrm{t} /$ 月体制が確立した。

同じ 46 年, ビスマス部門では, アノードまでの処理方法を乾式 に変更, 直採の向上及び省力化をはかつた。

50 年, バッテリースクラップを湿式法にて分離し，メタル分は $\mathrm{Sb}$ 系合金として, ペースト類は溶鍊部門を経て電気鉛として回 収をはじめた。

55 年, メンテナンスフリーバッテリーの素材である $\mathrm{Pb}-\mathrm{Ca}$ 合金の製造を開始したが，低 $\mathrm{Sb}$ 系との競合等，今後の需要動向 が注目される。

\section{$2 \cdot 4$ 公害防止関係}

45 年, 契島対岸の生野島に鍰堆積場を造成, 46 年には溶鍊系 排ガスの脱硫設備を完成させた。これまで製鍊所の象徵でもあり， 軍艦島としての偉容を誇つていた標高 $100 \mathrm{~m}$ のンクリート製大 煙突も, この脱硫設備の完成で 50 年に廃止し, 一世紀近い寿命 を閉じた。

48 年, 脱硫産物である亜硫酸カルシウムの酸化設備を, I H I (株)と共同開発し，石膏として外販する体制が整つた。

その他, D L プアガスや， B F 炬ガスの集じん設備を, 老朽化 したコットレルから, バグフィルタに転換, さらに作業環境維持 のためのバグフィルタの増設等, 逐次快適な環境づくりにも努力 してきた。

第 3 表に主要設備仕様を示す。

\section{3. 操 業の 概 要}

\section{3・1 焼結工程}

44 年, 大型 D Lの導入後, 送風バランスの確立や, パレット 上の $\mathrm{SO}_{2}$ 高濃度ガスのみを取出す装置の開発等により, 従来 4〜 